\title{
Non-traditional Security:a Study of Endogenous Cultural Security Based on the Buddha Event
}

\author{
Yang Dapeng ${ }^{1, a}$, Cui Jin ${ }^{1, b}$ and Pan Songting ${ }^{2, c}$ \\ ${ }^{1}$ School of public affairs, Zhejiang University, Hangzhou, China \\ ${ }^{2}$ Party school of Zhejiang provincial committee the CPC, Hangzhou, China \\ ayangdp@zju.edu.cn ${ }^{b}$ cuijin@zju.edu.cn ${ }^{\text {c} p a n s o n g t i n g 315 @ 163 . c o m ~}$
}

Keywords: Cultural security, nontraditional security management, endogenous security

\begin{abstract}
Cultural security is an important part of the non-traditional security. It is a problem that the national security needs to be considered. The cultural security is the 'basic value' and the 'cultural identity' of the 'national - nation' which is considered as a safe feeling. Endogenous security is always a difficult problem, in the cultural unity and the development of cultural diversity on the road, to build a new pattern through the perspective of cultural security.
\end{abstract}

\section{Introduction}

As is known to us all, traditional security mainly focuses on military security at the national level. However, non-traditional security concerns more about individual security issue, in other words, 'human security'. National security and political stability are bound together inextricably, and 'human security' is the ultimate goal of 'national security'. So no country should maintain its own safety by keeping other countries in danger. As an important part of non-traditional security, cultural security is a kind of security of the persistent fundamental value and culture characteristics from state and nation human belongs to. Cultural security is a multiple security including political cultural security, traditional cultural security, ethnic cultural security, educational security, religious security and so on.

Although safety culture appear in every corner of human development, however, the communication of ancient culture often appears in the form of military invasion or resistant, it is not a prominent factor of national security in the history, only in recent years, more attention has been paid to cultural security. But in fact, many military defeats are actually because of inevitable collapse of the national culture and national core values.

In our country, culture threats appear in many fields, such as intellectual property disputes, business cultural differences between China and other countries, the conflict to tourism and entertainment from SARS, etc. These security issues can be divided into the following points: The threat of cultural globalization, the threat of cultural hegemony and cultural strong, the threat of terrorism, the threat of cross-border trade and technology introduction, the threat of mass culture and consumarism, the threat of human right movements, the threat of long-term international and national cultural challenges and so on.

It is necessary for us to keep a comprehensive angle of view on cultural security research, as economic security, financial security, ecological security, public health security should be considered in combination. Due to the variation of the origin cultural threats come from, it also should be considered separately. In this paper, cultural security will be analyzed in endogenous.

\section{Sorts of China's Non-traditional Cultural Security}

\section{National religious culture security}

Religious culture is universal which has a common point in spirit. It tries to explain important mental problems in daily life and provides people sense of identity, sense of authority and spirit of idealism. As a special cultural pattern, religion will affect domestic politics, for example, Christians believe that "press freedom" is a meaningful activity to understand the world and the pursuit of truth, 
while the Islamic world believe that ' the Koran' is the only way to get truth. As a form of social ideology, religion culture can mobilize and unite the people, especially in the countries with caesaropapism.

There are about 300 million people who believe in different religions, $26 \%$ of which believe in folk deities. Therefore, there is a certain security threat around the religious development, for instance, legal and illegal missionizing, a sharp increase in the number of believers and the wide foundation of folk religion. The correctness and advancement of national political ideology can not entirely take the place of national and people's religious ideology., and Chinese cultural construction can not be separated from the reality of long-term Chinese religious culture and tradition. This is the central idea of contemporary Chinese social governance, the core value of social system and one of the most important part of political cultural security.

\section{National Cultural heritage security}

The traditional culture of a country always comes from a long history of accumulation and development, it is the sum of national survival and development as well as an outcome of adaptation and choices from challenges. tangible and intangible cultural heritages including lifestyle, settlement form, organization, history books, literature, art, architecture and so on, are valuable national cultural ecologies and collective cultural genes.

In China, historic buildings and sites are constantly damaged, while historical and cultural classics are misappropriated or overdeveloped, the situation is extremely serious. The threats to tangible cultural heritages can be summarized as the following points: public or private engineering, the rapid development of tourism (such as the destruction of Zhenhai old town), land shifts and armed conflicts. In consideration of intangible cultural heritages, other factors come to our eyes: the great change of cultural environment, the lack of relevant laws and regulations, the weakness of protection consciousness and the excessive consumption of cultural heritages.

\section{Ethnic culture and local culture security}

Non-traditional security is also concerned about the safety and interaction of national security and multinational culture. The living conditions of multi ethnic relations in different countries and the relationship between strong national culture and marginalized minority are the latest national cultural security. In multiple ethnic cultures and local cultural security, ethnic separatism, ethnic cultural conflicts, lack of local culture and ethno-nationalism of the Han should be alert to.

For example, a large violent event happened in Baicheng, Xinjiang Province on September 18, 2015, at least 60 people were killed , most of whom work as miners from all around the countryside. As most of citizens in Baicheng are Muslim uighurs, some of them took up weapons to fight against the Han, considering that the Han settlers were invading their religious and cultural traditions on purpose. However, this disaster is because of pollution or land disputes in fact.

\section{Characteristics of China's Non-tradition Cultural Security}

The endogenous cultural threats often come from non-state actors. These threats hide deeply in the social system and occur in the internal state as they have a profound institutional structural causes such as economic growth, political transformation, social transformation, etc. Cultural Security has the following characteristics:

\section{Independence.}

Despite culture security needs the support of economic security and political security, culture itself has its characteristic independence, in the international system of a country or a nation's culture, it is the core problem to maintain the internal cohesion, continuity and the external integrity. Therefore, culture security should be considered independently.

\section{Stability.}

Cultural security is one of the most sturdy form of safety, and it is also the soul of the country. As cultural security is a kind of security of the persistent fundamental value and culture characteristics from state and nation human belongs to, it cannot be destroyed without a hitch.

\section{Chronicity.}

Cultural safety is a necessary condition and the basic guarantee of the development of a state. 
Therefore, cultural safety is a long-term problem with the history of a nation or a state.

\section{Potentiality.}

Cultural Security hides in the deepest national security section. Its outer reflection is usually economic, political and even military conflict, but when we raise our sights onto cultural security, the core will be specific, especially in theocratic countries.

\section{National traits.}

Cultural security is a pluralistic security issue, which is related to a comprehensive reflection of various ethnic cultures. The cultural security is also a reflection of the culture of a national state, which makes a sovereign state different from other countries.

\section{Case Study of China's Non-traditional Cultural Security}

Non-traditional cultural security a relatively broad coverage and its content is relatively complex this paper will secure non-traditional cultural heritage as a case study.

\section{Incident of the event}

The Buddha Temple is located in Si County, Anhui Province, which is rewarded as 'Chinese folk culture and art village'. However, in order to develop the realty business, the Si County government decided to take down the Buddha Temple and build houses instead through competitive auction. Today, due to the perfect support of the location, schools, squares, markets, the houses still under construction sell well, the price has reached $¥ 2,700 / \mathrm{m} 2$, which is becoming one of the local high-priced real estate, but most of the parts of Buddha Temple have been removed in addition to a Buddha carved stone.

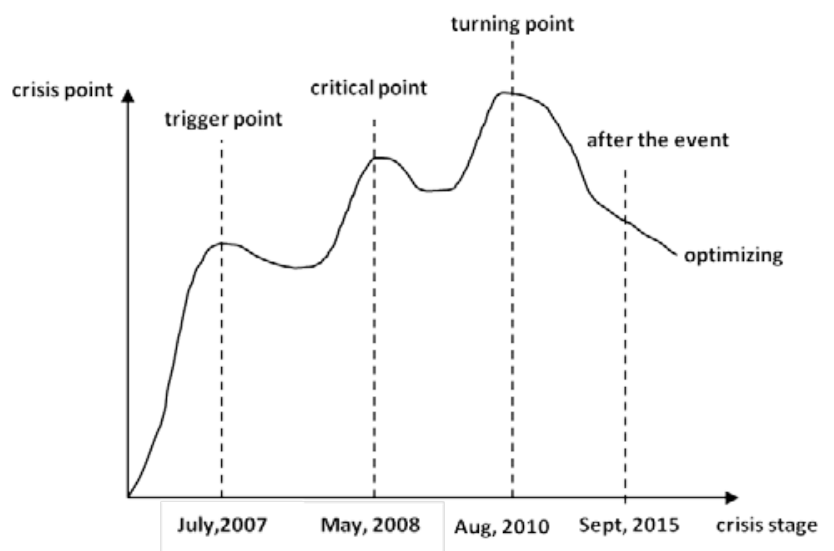

\section{The case background}

In recent years, news of tangible cultural heritages taking down by commercial use burst out frequently. Song and yuan granary sites, which are known as 'the national top ten archaeological discoveries 'from zhenjiang, jiangsu province, were ruined by developers to build premises. The same thing also happened to the city god temple, the state protected monuments of ezhou, hubei province. What's more, the three parallel rivers region, forbidden city, temple of heaven, the summer palace, old town of lijiang as well as the potala palace are overdeveloped commercially.

\section{The trigger point}

The buddha temple is located in state-owned land. The county land bureau held a bidding auction for 25 acres lands including the buddha temple at the request of upper superior. The lands were sold for $¥ 11.5$ million, which had set a new price record. As the masses heard about what would happen to the buddha temple, they called for attention actively and wrote to respective departments to ask if they could repair and save the buddha temple by themselves. Eventually they got no response.

\section{The critical point}

As the lands around the buddha temple were in preparation for construction, the county culture bureau took action as soon as they heard about the buddha temple was getting destroyed. Although cultural relics protection notice and suspension request were assigned several times, the 
construction didn't stop anyway. The county culture bureau decided to inform their superiors about the neglect of the construction team. The national heritage board even sent letters to ask for report of the protection of the buddha temple. However, the pressure from local government was too heavy to get rid of. The construction team said that the county culture bureau should say ok about commercial development as they had offered the cost of archaeological digs.

At the coordination meeting held by county government, the county culture bureau insisted on protection in place while the local government mandated to reconstruct in another place. According to the cultural relics protection law, the protection and reconstruction of immovable cultural relics such as the buddha temple must be reported and approved by relevant departments of provincial people's government. However, the si county local government made a decision just by the county government meeting minutes.

\section{The turning point}

The inspection team held a meeting on the question of the buddha temple at the si county on aug. 25,2010 . the state administration of cultural heritage inspectorate division came up with 5 comments during the meeting: stop violation and clean up the site, clarify the facts and assess the loss, insist on accountability according to the law, supervise the rectification and protect scientifically, strengthen work by taking lessons. Several measures were also raised by the director of cultural relics bureau of anhui province, chen jianguo. According to the requirements from state administration of cultural heritage inspectorate division and the provincial cultural relics bureau, the local government should report the result and measures before september, and it was proved to journalists that 'the reconstruction method' had changed to 'the protection in place method'. The local government asked the construction team to stop the commercial project totally, and the company owner was fined $¥ 400,000$.

In september 18, the cultural relics protection units of si county published the result of buddha temple event, 7 cadres including si county party secretary gained judicial punishment.

\section{The end of the case}

In sept 19, 2015, the county political consultative conference came up with a suggestion that incense of the buddha temple should be renewed.

\section{Strategy of China's Non-traditional Cultural Security}

\section{Dynamic view of non-traditional culture security}

Culture is not isolated nor stationary. Different cultures are always in a state of interaction and transition. A country's system is the accumulation and extension of its historical traditions and cultural identity. And the historical traditions and cultural identity as well as political belief movement can result in the rising of a country. The concept of cultural policy should be extended, not only from art and architecture in a narrow point of view, but also a new perspective and diverse cultural policy issues should be focused on. A variety of cultural and artistic forms as well as means of communication should be supported, and cultural diversity should be encouraged.

\section{Emphasis on national ideology construction}

With the restoration of outstanding traditional cultural elements, the traditional bad habits also reproduces, including corruption, dogmatism and civil consequent distrust of political ideology. These are all endogenous. The teaching result of Chinese universities leaves a limited ideological influence on China's national polity. The popularity of scientific rational thinking has made young people modest and prudent to China's political ideology. There are also significant changes in personal morality and lifestyle choices, such as the more rational attitude towards social interaction, and the more attention paid to economic interests and individual rights. The current political ideology innovation should be started with the following three aspects: be concerned about the livelihood problems, effectively promote fair and identify scales of justice.

The difference between China's political ideology and national ideology distinction is not obvious at this stage. National aesthetic ideology, life ideology, religious ideology, historical ideology, economic ideology and technological ideology should be made good use of. In the political ideology of the national security, national publicity and education departments have a 
special mission and responsibility, in the current trend of economic globalization, information networking, media and entertainment, aesthetic ideologies, life ideologies as well as technology ideologies considering national interests and development strategies should be well advertised and educated. Promote rational, healthy, active, honest and ethical literature, lifestyle as well as technology by effective and reasonable system has become as important as the construction and maintenance of the country's political ideology.

\section{Cultural innovation spirit for quality promotion}

Change and innovation is not only the trend of the historical development of human society, but also the inherent requirements of China's social development. Modernization process is the social integration of systems engineering, it is important to improve and develop the national innovation system. This course also includes innovative new culture, Especially the support of new ideas. Therefore, it is our responsibility to carry forward the spirit of innovation of ideas and culture as well as establish and develop a new kind of socialist ideology. Security is a major part of contemporary culture national security system, including a plurality of values and national quality and other aspects. It is the most important moment of cultural innovation to maintain an indigenous self-organization and management system values, the notion of political systems and supporting mechanism for social management.

\section{Acknowledgement}

This research was financially supported by the National Natural Science Foundation of China (Grant NO. 71473229) and Zhejiang Provincial Natural Science Foundation of China(Grant NO. LQ14G030024).

\section{References}

[1] Knapp K J, Marshall T E, Kelly Rainer R, et al. Information security: management's effect on culture and policy[J]. Information Management \& Computer Security, 2006, 14(1): 24-36.

[2] Rothbaum F, Weisz J, Pott M, et al. Attachment and culture: Security in the United States and Japan[J]. American Psychologist, 2000, 55(10): 1093.

[3] Katzenstein P J. The culture of national security: Norms and identity in world politics[M]. Columbia University Press, 1996.

[4] Yaqing B Q. National Identity, Strategic Culture, and Security Interests: Three Hypotheses on the Interaction between China and the International Community $[\mathrm{J}][\mathrm{J}]$. World economics and politics, 2003, 1: 001.

[5] Xue-fang X I E. Analysis of Cultural Security Research in China Since 1999 [J][J]. Journal of Jiangnan Social University, 2007, 3: 001.

[6] Zhong-ying S H I. Cultural security in China[J]. Journal of Beijing Normal University (Social Science Edition), 2004, 3: 001.

[7] QI Lin. Review of domestic non-traditional security issues[J]. Journal of University of International Relations,2005, 1(01): 28-33.

[8] Eide A. Economic and social rights[M]. na, 2000.

[9] Huntington S P. The clash of civilizations?[J]. Foreign affairs, 1993: 22-49.

[10]Tomlinson J. Globalization and culture[M]. University of Chicago Press, 1999.

[11]HU Hui-lin. The development of cultural industries and national cultural security[M]. Guangdong People's Publishing House, 2005

[12]WANG Yi-zhou China and non-traditional security[J]. International Economic Review, 2005 (6): 32-35.

[13]HU Hui-lin. China national cultural security theory[M]. Shanghai People's Publishing House, 2005.

[14]HU Hui-lin. China National Cultural Security Report[M]. Shanghai People's Publishing House, 2005. 